Scientific Review - Engineering and Environmental Sciences (2020), 29 (2), 155-171

Sci. Rev. Eng. Env. Sci. (2020), 29 (2)

Przegląd Naukowy - Inżynieria i Kształtowanie Środowiska (2020), 29 (2), 155-171

Prz. Nauk. Inż. Kszt. Środ. (2020), 29 (2)

http://iks.pn.sggw.pl

DOI 10.22630/PNIKS.2020.29.2.14

Sarah Mustafa AHMED ${ }^{1}$, Omer Muhie Eldeen TAHA ${ }^{2}$, Mohamed A. NAJEMALDEN ${ }^{3}$, Rehab T. AHMED ${ }^{3}$, Ali A. ABEDULWAHAB ${ }^{3}$

${ }^{1}$ University of Kirkuk, Environmental Research Unit

${ }^{2}$ University of Kirkuk, College of Engineering

${ }^{3}$ Iraqi Ministry of Health and Environment

\title{
Assessment of Lower Zab river water quality using both Canadian Water Quality Index Method and NSF Water Quality Index Method
}

Key words: NSF Water Quality Index, Canadian Water Quality Index, Lower Zab river, physicochemical parameters, dissolved oxygen, biochemical oxygen demand

\section{Introduction}

Water is well known as the main constituent of Earth's streams, lakes, and oceans, and the fluids of most of earth organisms. It is essential for all known forms of life. During the last decades of the 20th century polluted water has started to become a universal grave issue and surface water quality is becoming a real global concern (Witek \& Jarosiewicz, 2009). Human existence, development and well-being have always been linked to water (Eulisse, 2010; Reza \& Singh, 2010). Over two thirds of Earth's surface are covered by water, which represent about $71 \%$ of the Earth's surface, and more than $96 \%$ of this water is saline. Over $68 \%$ of freshwater is in ice and glaciers and $30 \%$ is confined in the ground. The rest (about 1.2\%) represent the fresh surface-water sources, such as rivers and lakes (Shiklomanov, 1993). Rivers are considered the most important sources of surface water on Earth. They are play a significant role in all human activities, like agriculture, drinking, irrigation, industry, and domestic work. Many industries rely in their processes on water, and about $40 \%$ of food supply around the world is grown under irrigation (BCAS, 2000). However, all these activities have posed a major threat to the quality of the river's water in many countries around the world particularly in developing countries and some drink- 
ing water supplies have become contaminated (Akoto \& Adiyiah, 2007). The United Nations reports pointed that a child dies every 8 second as a result of a water-related illness (Al-Adawi, 2005). As noted by the World Health Organization (WHO), 3.4 million people, mostly children, die annually from water-related diseases (WHO, 2001). Beside the anthropogenic influences such as urban, industrial, and agricultural activities, there are many factors that affect water quality characteristics such as natural processes like climate, precipitation inputs and catchment area, tectonic, erosion of crustal materials and bedrock geology, in combine with the influence of the environment (Glińska-Lewczuk, 2006; Nas, Bayram, Nas \& Bulut, 2008; Kašiarová \& Feszterová, 2010).

Therefore, many studies conducted to evaluate water quality index in different rivers and water bodies around the world. The importance of the water quality index is emerged through providing data base about quality of the water source, and explain the change in the water quality over a period of time, as well as finding the degree of pollution of a water body (Al-Heety, Turki \& Al-Othman, 2011; Phadatare \& Gawande, 2016). The pollution of Iraqi waters is one of the major problems that have started to appear and have increased. This necessitates serious thinking to find ways to combat and minimize the water pollution, especially as the rivers and lakes attract human communities and often most of the villages and cities in Iraq are located on the edges of rivers and lakes (Shahin, 2007). As the river was a source of all the requirements of people from water in return were dumping waste and wastewater to this river, which led to pollution of river.

Thus, the current study involved determination of physicochemical and biological parameters of Lower Zab river in Kirkuk city at different points. This study aims to evaluate the water quality of Lower Zab river by analyzing of some selected water quality parameters like: $\mathrm{pH}$, total dissolved solids, biochemical oxygen demand, dissolved oxygen, turbidity, electrical conductivity, alkalinity, and salinity etc., and compare the results with the Canadian Council of Ministers of the Environment (CCME) and the $\mathrm{Na}$ tional Sanitation Foundation (NSF) water quality index (CCME, 2001).

\section{Material and methods}

\section{Study area}

In Iraq there are two main rivers considered the lifeline of the country. Tigris is the eastern of the two great rivers that define Mesopotamia, the other being the Euphrates (Frenken, 2009). Flowing into the Tigris river, within the borders of Iraq, a large group of tributaries supplying more than half of the Tigris in the flood season, scattered in the territory of Turkey, Iran and Iraq, the most important Khabur, Great Zab, Lower Zab, Al-Adhaim, and Diyala. Lower Zab river (also named as Little $\mathrm{Zab}$ ) is one of the five main catchments in Northern Iraq (Frenken, 2009; Saeedrashed \& Guven, 2013). The Lower Zab begins in Iran in a mountainous range which is part of the Zagros mountains (Kliot, 2005; Frenken, 2009). Its equipped with the Dukan Dam $\left(6.8 \mathrm{~km}^{3}\right)$ in Sulaymaniyah city in Iraq (Frenken, 2009). The river basin of 
$21,475 \mathrm{~km}^{2}$ generates about $7.17 \mathrm{~km}^{3}$, of which $5.07 \mathrm{~km}^{3}$ of annual safe yield after buildup Dokan Dam (Frenken, 2009). The total length of the river is $400 \mathrm{~km}$ (Kassim, Sabri \& Salman, 2007; Shahin, 2007; Jabar, 2008). The Lower Zab river is lying between the geographic coordinates of SN latitude $35.16^{\circ}$ to $36.79^{\circ}$ and WE longitude $43.39^{\circ}$ to $46.26^{\circ}$, and it is going over within the administrative boundaries of the governorates: Erbil, Sulaymaniyah, and Kirkuk (Saeedrashed $\&$ Guven, 2013). About $30 \mathrm{~km}$ north of Fatha, the Lower Zab joins the river Tigris (Al-Ansari, 2016). The river water depends on the melting of snow in the mountains and the amount of rainfall, which fluctuates from year to year according to climatic conditions, where the water level is the highest level in the spring because of melting snow and less in the summer. The Lower Zab river is the major source for drinking water in Kirkuk Governorate, as well as for agriculture and irrigation in the region.

The study of the water quality index of the Lower Zab river within the administrative boundaries of Kirkuk Governorate, where two monitoring points are adopted for the purpose of modeling. These points approved by the Ministry of health and environment in Iraq - Directorate of Protection and Improvement of the Environment of the Northern Region. The monitoring stations were adopted within the geographical area of the province of Kirkuk, which is LZ2 (Lower Zab station 2) and LZ3 (Lower Zab station 3). The first monitoring point (LZ2) is located in Alton Kobri (GPS coordinates $35.76053 \mathrm{~N}, 44.14189$ E) which is a small town located northwest of Kirkuk city and it is about 40-kilometer distance. The second monitoring point (LZ3) located in Dibs District (GPS coordinates $35.68447 \mathrm{~N}$, $44.07072 \mathrm{E})$ about $35 \mathrm{~km}$ northwestern Kirkuk city (Fig. 1).

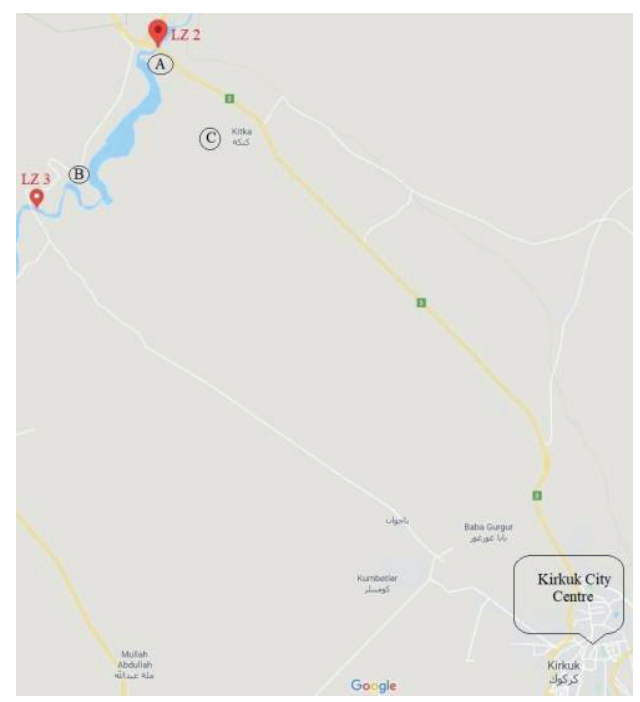

FIGURE 1. Location of stations on the Lower Zab river

Many human and industrial activities taking place near the Lower Zab river and along the riverbed, like the discharges of the power plant of Dibs and the residues of stone quarries and block factories are considered threats to the quality of water in the Zab river. Also, the existence of agricultural fields near the riverbed which affects the increase of pollution by returning the water used for irrigation to the riverbed, which is loaded with pollutants of fertilizers and salts. In addition, there is a discharge of Karwanchi Beverage Factory (Soft drink factory), which is disposed to the Lower Zab river in the area confined between LZ2 and LZ3. The main problem that cause pollution in the Lower Zab river are from the 
TABLE 1. Location and name of the polluting activity of the Lower Zab river

\begin{tabular}{|l|l|c|}
\hline Location & \multicolumn{1}{|c|}{ Waste type } & Symbol \\
\hline Kirkuk - Alton Kubri & untreated sewage water of residential houses & A \\
\hline Kirkuk - Dibs & untreated sewage water of residential houses & B \\
\hline $\begin{array}{l}\text { Kirkuk - Karwanchi Group Company } \\
\text { for Soft Drink Juices Water }\end{array}$ & $\begin{array}{l}\text { - treated sewage water } \\
- \text { untreated industrial wastewater }\end{array}$ & C \\
\hline
\end{tabular}

discharging the sewage water of Hawija, Debs, Alton Kubri and Zab areas directly into the river body. All these places do not have sanitation projects. All the polluting activity between the LZ2 and LZ3 are listed in Table 1.

\section{Sample collection}

Raw water samples were collected from the Lower Zab river twice a month by one sample every 15 days from each station. The samples collected from January 2013 to March 2019. Water samples were taken from about 3 to $4 \mathrm{~m}$ from the edge of the river at a depth of $20-30 \mathrm{~cm}$ from the water surface of the river. The water quality data include 16 parameters: $\mathrm{pH}$, dissolved oxygen (DO), biochemical oxygen demand (BOD), phosphates $\left(\mathrm{PO}_{4}\right)$, nitrate $\left(\mathrm{NO}_{3}\right)$, calcium $(\mathrm{Ca})$, magnesium $(\mathrm{Mg})$, total hardness $(\mathrm{TH})$, potassium $(\mathrm{K})$, sodium $(\mathrm{Na})$, sulfates $\left(\mathrm{SO}_{4}\right)$, chlorides $(\mathrm{Cl})$, total dissolved solids (TDS), electrical conductivity (EC), alkalinity (ALK), and turbidity (TRUB). The data of the sixteen parameters included in this study was obtained from Directorate of Protection and Improvement of the Environment - Northern Region (Kirkuk, Iraq). The standard used here was the Canadian Drinking Water Guidelines and if there was no Canadian standard, Iraqi standard for drinking water or the World Health Organization guidelines are used (IQS 417, 2009; WHO, 2017). Collected samples were taken by sterilized bottles from the middle of the stream. Tests were carried out following the American Public Health Association (APHA, 1995) standard methods.

\section{Water quality indices calculations}

A number of water quality indices have been formulated over the last five decades. First formulated of WQI was by Horton (1965). It is commonly used for the detection and estimating of water pollution based on several quality parameters (Horton, 1965). This index provides a single number which expresses overall water quality at a certain location and time by simplify complex data into simple information that is easy to understand and usable by the public (Schultz, 2001). Many WQI studies have been conducted all over the world in different countries, they were reported in literature by many researchers (Brown, McClelland, Deininger \& Tozer, 1970; Fulazzaky, 2009; Tyagi, Sharma, Singh \& Dobhal, 2013; Gupta, Pandey \& Hussain, 2017). Many studies developed numerous water quality indicators to provide a convenient way to summarize water quality data, each using different group of analytes (House \& Ellis, 1987). In this study two water quality methods used to assess the quality of Lower Zab river (NFS Method and CCME Method). 


\section{National Sanitation Foundation (NFS)}

The NFS WQI is a commonly-used water quality index developed by the National Sanitation Foundation in 1970 to provide a standardized way to compare the water quality of different water bodies. In this method, weight was assigned for each parameter where the sum of the weights is equal to one (Brown et al., 1970). The water quality results can be reported using descriptive words to summarize the data into one of five classes, ranging from "very bad" to "excellent" (Ott, 1978). This type of WQI ignores the type of water consumption, therefore it can be used for various water bodies types (Ott, 1978). It is useful for estimating spatial and temporal changes and classify the quality of river water (Reza $\&$ Singh, 2010), and groundwater source (Rajankar, Gulhane, Tambekar, Ramteke \& Wate, 2009).

The NFS WQI is designed to include nine parameters, they are dissolved oxygen (DO), five-day biochemical oxygen demand $\left(\mathrm{BOD}_{5}\right)$, nitrate, total phosphate, temperature, turbidity, fecal coliform, and total solids (Brown et al., 1970). It can still be calculated if there are some missing parameters (Srivastava \& $\mathrm{Ku}-$ mar, 2013), or further parameters more than nine (Kumar \& Alappat, 2009; Ewaid, Abed \& Kadhum, 2018). When it is difficult to find the concentration of all nine quality parameters, the weight of the missing parameters will be distributed over other parameters based on the weight of each parameter in the index.

The result of WQI with missing parameters will be different from the real result if all the nine parameters adopted, but the difference is very low that made the classification of quality index still in the same class (Srivastava \& Kumar, 2013). However, it is clear that choosing a small number of water quality parameters are not met the objectives well, while if a large number of parameters are used a different picture will be provide (CCME, 2001). In the literature some researchers used fewer than nine variables in water quality studies (Al-Mutairi, Abahussain \& El-Battay, 2014; Gupta et al., 2017; Ebuete \& Ebuete, 2018). While others used more variables to obtain a more comprehensive picture of water quality (Alobaidy, Abid \& Maulood, 2010; Ewaid et al., 2018). The parameters and their corresponding weights are listed in Table 2 (Kumar \& Alappat, 2009; Ewaid et al., 2018).

The mathematical equations for WQI are given as follows:

$Q_{i}=\left(\frac{Q_{\text {actual }}-Q_{\text {ideal }}}{Q_{\text {standard }}-Q_{\text {ideal }}}\right) 100$

$N S F W Q I=\sum_{i=1}^{n} W_{i} Q_{i}$

where:

$Q_{i}-$ sub-index for $i^{\text {th }}$ water quality parameter,

$n$-number of water quality parameter, $W_{i}$-weight (in terms of importance) associated with $i^{\text {th }}$ water quality parameter.

\section{The Canadian Council of Ministers of the Environment (CCME)}

The CCME WAI Method is a widely used and globally accepted model for assessing the water quality (Khan, Pa- 
TABLE 2. NSF WQI parameters and weights (Ott, 1978; Kumar \& Alappat, 2009; Batabyal \& Chakraborty, 2015; Ewaid et al., 2018)

\begin{tabular}{|c|c|c|c|c|c|}
\hline Parameter & Unit & $\begin{array}{c}\text { Assigned } \\
\text { weight } \\
\left(w_{i}\right)\end{array}$ & $\begin{array}{c}\text { Relative } \\
\text { weight } \\
W_{i}=\frac{w_{i}}{\sum_{1}^{n} w_{i}}\end{array}$ & Standard & Reference \\
\hline $\mathrm{pH}$ & - & 4.33 & 0.0894 & $6.5-8.5$ & - \\
\hline Dissolved oxygen (DO) & \multirow{12}{*}{$\mathrm{mg} \cdot \mathrm{l}^{-1}$} & 4.59 & 0.0947 & $4.0-6.5$ & - \\
\hline $\begin{array}{l}\text { Five-day biochemical oxygen } \\
\text { demand }\left(\mathrm{BOD}_{5}\right)\end{array}$ & & 3.88 & 0.0801 & 3 & WHO, 2017 \\
\hline Phosphates $\left(\mathrm{PO}_{4}\right)$ concentration & & 3.89 & 0.0803 & 0.4 & IQS 417, 2009 \\
\hline Nitrate $\left(\mathrm{NO}_{3}\right)$ concentration & & 3.8 & 0.0784 & 1 & - \\
\hline Calcium $(\mathrm{Ca})$ concentration & & 1.96 & 0.0405 & 25 & - \\
\hline Magnesium $(\mathrm{Mg})$ concentration & & 1.76 & 0.0363 & 50 & - \\
\hline Total hardness $(\mathrm{TH})$ & & 2.84 & 0.0586 & 250 & - \\
\hline Potassium $(\mathrm{K})$ concentration & & 0.94 & 0.0194 & 8 & - \\
\hline Sodium $(\mathrm{Na})$ concentration & & 0.94 & 0.0194 & 20 & - \\
\hline Sulfates $\left(\mathrm{SO}_{4}\right)$ concentration & & 2.64 & 0.0545 & 250 & IQS 417, 2009 \\
\hline Chlorides $(\mathrm{Cl})$ concentration & & 3.43 & 0.0708 & 250 & - \\
\hline Total dissolved solids (TDS) & & 3.63 & 0.0749 & 450 & - \\
\hline Electrical conductivity (EC) & $\mu \mathrm{S} \cdot \mathrm{cm}^{-1}$ & 3.22 & 0.0665 & 1600 & - \\
\hline Alkalinity (ALK) & $\mathrm{mg} \cdot \mathrm{l}^{-1}$ & 3.13 & 0.0646 & 250 & WHO, 2017 \\
\hline Turbidity (TRUB) & NTU & 3.47 & 0.0716 & 5 & - \\
\hline
\end{tabular}

TABLE 3. Water Quality Index (WQI) ranges (Batabyal \& Chakraborty, 2015)

\begin{tabular}{|l|c|}
\hline Criteria & WQI range \\
\hline Excellent & $0-50$ \\
\hline Good & $50-100$ \\
\hline Poor & $100-200$ \\
\hline Very poor & $200-300$ \\
\hline Unsuitable for drinking & $>300$ \\
\hline
\end{tabular}

terson \& Khan, 2004). It is based on a formula developed by the British Columbia Ministry of Environment, Lands and Parks and modified by Alberta Environment (CCME, 2001). This index has been extensively used in water quality studies because its flexibility in terms of the type and number of variables selected for testing quality of water and the type of water body, also the time period of application. Another advantage of this model is enabling the researchers to use the national standards for water quality (A.A. Khan, Tobin, Paterson, Khan \& Warren, 2005). Many studies have been conducted to determine water quality in different countries (Khan et al., 2004; Lumb, Halliwell \& Sharma, 2006; Damo \& Icka, 2013; Munna, Chowdhury, Ahmed, Chowdhury \& Alom, 2013; Mahagamage \& Manage, 2014; Gupta et al., 
2017). The CCME WQI model consists of three factors:

1. Scope: represents the number of variables that do not meet their objectives.

2. Frequency: represents the number of times these objectives are not met.

3. Amplitude: represents the amount by which the objectives are not met.

These factors produce a number value (from 0 to 100 ) refers to the total water quality for the water body, where 0 represents the "worst" and 100 represents the "best" value for water quality (CCME, 2001; H. Khan, Khan \& Hall, 2005; Lumb et al., 2006; Panduranga Murthy \& Hosmani, 2009). The formulation of the WQI as described in the Canadian Water Quality Index 1.0 - Technical Report, is shown in the following equations (Munna et al., 2013): The measure for scope is $F_{1}$. This represents the number of variables whose value does not match the objectives over the study time period.

$$
F_{1}=\left(\frac{\text { number of failed variables }}{\text { total number of variables }}\right) 100
$$

The measure for frequency is $F_{2}$. This represents the failed tests which is the percentage of individual tests that do not meet objectives.

$F_{2}=\left(\frac{\text { number of failed tests }}{\text { total number of tests }}\right) 100$

The measure for amplitude is $F_{3}$. This represents the number of failed test values that do not meet their objectives. This step consists of several phases. Initially calculation of Excursion, the number of times by which the test value is greater than the objective, the excursion calculated from the following equation

excursion $=\left(\frac{\text { failed test value }}{\text { guidelinevalue }}\right) 100$

For the cases in which the test value is less than the objective, formula (6) is used

excursion $=\left(\frac{\text { guideline value }}{\text { failed test value }}\right)-1$

The normalized sum of excursions (nse) can be calcalated by equation (7)

nse $=\frac{\sum_{i=1}^{n} \text { excursion }}{\text { number of tests }}$

Finally, the amplitude $\left(F_{3}\right)$ can be found from equation (8)

$F_{3}=\frac{n s e}{0.01 n s e+0.01}$

The CCME WQI is then calculated as shown in the following equation

$W Q I=100-\left(\frac{\sqrt{F_{1}^{2}+F_{2}^{2}+F_{3}^{2}}}{1.732}\right)$

then the value of water quality can be ranked by relating it to one of the five categories set out in Table 4.

The main pollution parameters that considered for surface water quality management in this work include 16 parameters: turbidity (TRUB), $\mathrm{pH}$, dissolved oxygen (DO), five-day biochemical oxygen demand $\left(\mathrm{BOD}_{5}\right)$, total dissolved solids (TDS), total hardness (TH), electrical conductivity (EC), alkalinity 
TABLE 4. CCME WQI categorization schema (CCME, 2001; H. Khan et al., 2005)

\begin{tabular}{|c|c|c|}
\hline Category & WQI & Status \\
\hline 1 & $95-100$ & excellent \\
\hline 2 & $80-94$ & good \\
\hline 3 & $65-79$ & fair \\
\hline 4 & $45-64$ & marginal \\
\hline 5 & $0-44$ & poor \\
\hline
\end{tabular}

(ALK), concentration of: nitrate $\left(\mathrm{NO}_{3}\right)$, phosphorus $\left(\mathrm{PO}_{4}\right)$, calcium $(\mathrm{Ca})$, magnesium $(\mathrm{Mg})$, sulfates $\left(\mathrm{SO}_{4}\right)$, potassium $(\mathrm{K})$, sodium $(\mathrm{Na})$, and chlorides $(\mathrm{Cl})$.

\section{Result and discussion}

The results for the descriptive data of the 16 water quality variables $(\mathrm{pH}, \mathrm{DO}$, BOD, TDS, EC, ALK, TH, TRUB, concentration of $\mathrm{PO}_{4}, \mathrm{NO}_{3}, \mathrm{Ca}, \mathrm{Mg}, \mathrm{K}, \mathrm{Na}$, $\mathrm{SO}_{4}, \mathrm{Cl}$ ), which were measured twice a month during sampling period of seven years (from 2013 to 2019) at two stations on the Lower Zab river, were analyzed and presented in Figures 2, 3, 4, and 5. The investigation of the physical and chemical parameters results gives a broad understanding for water quality

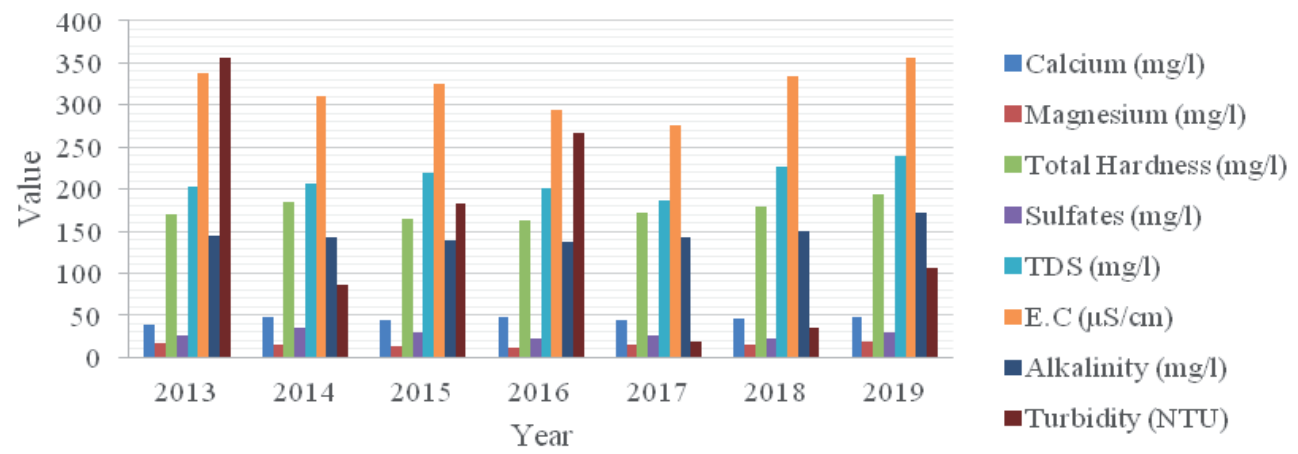

FIGURE 2. Trend of calcium, magnesium, total hardness, sulfates, TDS, EC, alkalinity, and turbidity for LZ2 station

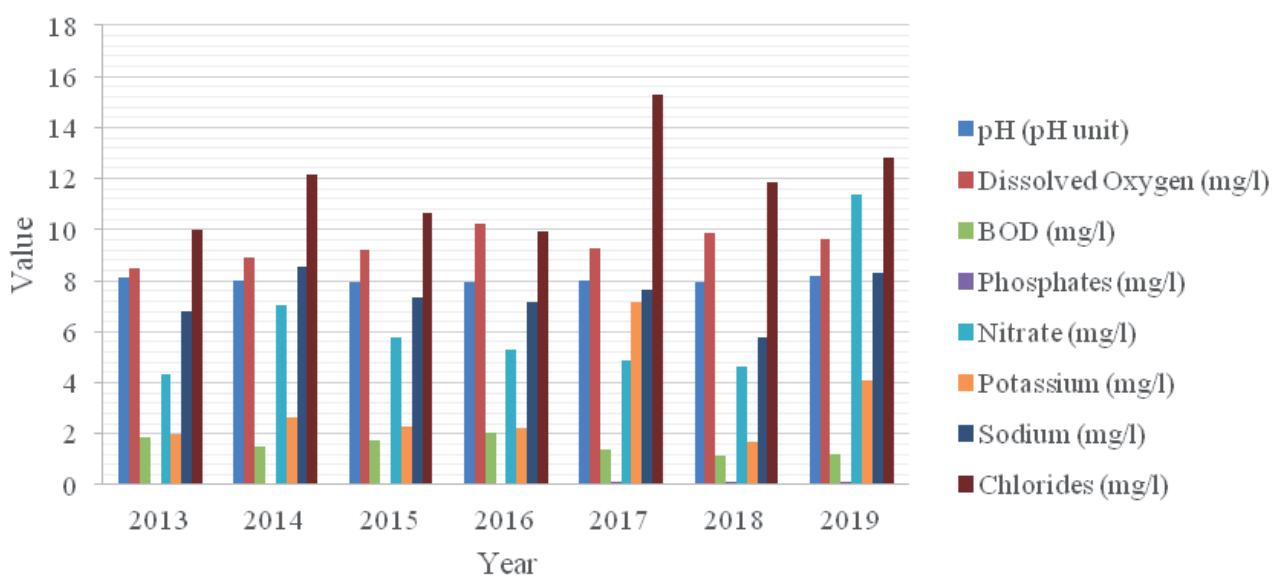

FIGURE 3. Trend of $\mathrm{pH}$, dissolved oxygen, BOD, phosphates, nitrate, potassium, sodium, and chlorides for LZ2 station 


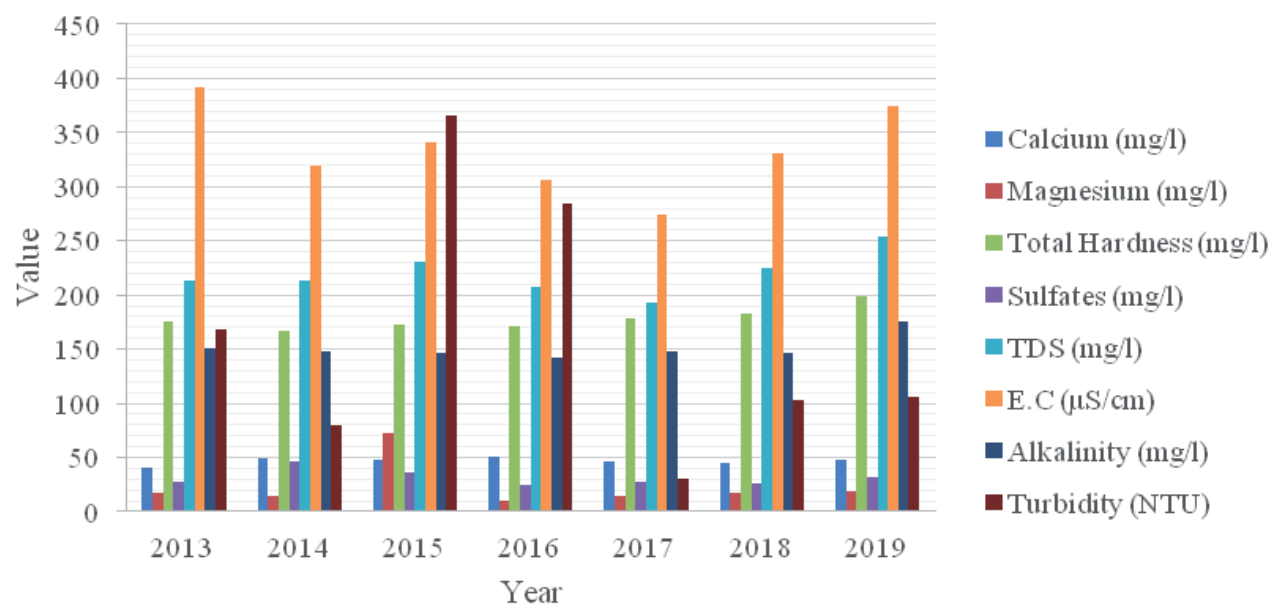

FIGURE 4. Trend of calcium, magnesium, total hardness, sulfates, TDS, EC, alkalinity, and turbidity LZ3 station

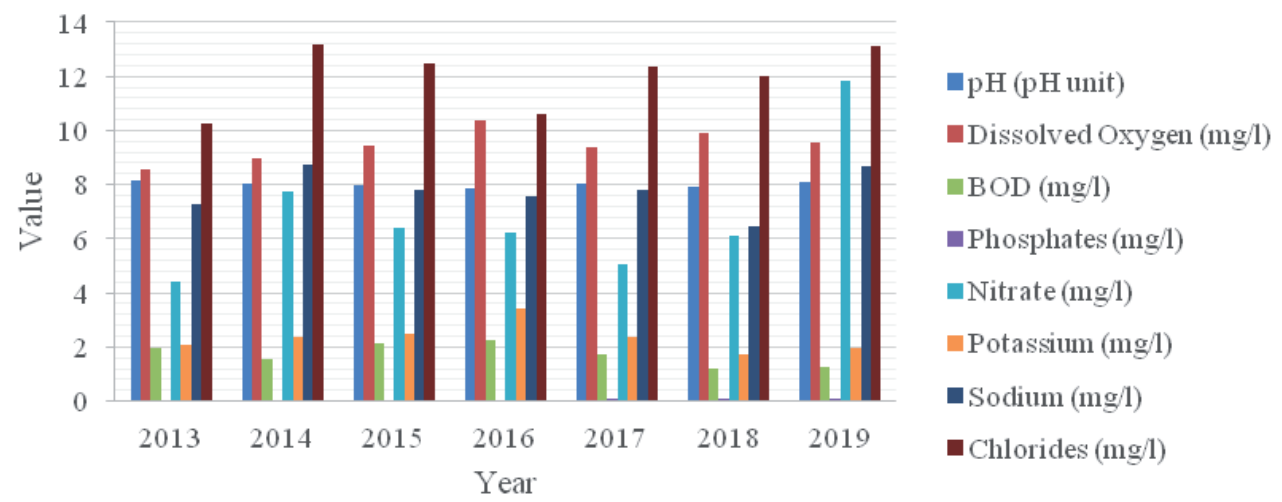

FIGURE 5. Trend of $\mathrm{pH}$, dissolved oxygen, BOD, phosphates, nitrate, potassium, sodium, and chlorides for LZ3 station

of the river by finding out the parameters responsible for detraction the water quality.

The results show that all parameters values were within the standards of drinking water proposed by the CCME standards (2001), Iraqi standards (IQS 417, 2009), and the WHO standards (WHO, 2017) for drinking purpose, except turbidity, dissolved oxygen, concentration of nitrate and calcium, which were mostly higher than the standards and occasionally biochemical oxygen demand and concentration of potassium.

The $\mathrm{pH}$ measure reflects the acid content of the water source. According to the standards produced by the CCME, the WHO, and Iraq standards for drinking water (IQS 417, 2009), the range of $\mathrm{pH}$ lies between 6.5 and 8.5. Alkaline water with $\mathrm{pH}$ level higher than 8.5 is produce salty taste for water and caused eye ir- 
ritation. If the $\mathrm{pH}$ is less than 6.5 water produce sour taste and classified as acidic water. Acidity water does not have useful minerals for human body (Nollet, 2004; Kumari, Sudhakar, Sri, \& Sree, 2011). In this study, the $\mathrm{pH}$ values ranged from 7.7 to 8.38 which follow the standards given by the CCME, the WHO, and the Central Organization for Standardization and Quality Control (COSQC). That narrow range of $\mathrm{pH}$ variation of $\mathrm{pH}$ indicates a slightly alkaline water (Rabee, Abdul-Kareem \& Al-Dhamin, 2011).

Dissolved oxygen is an important parameter in calculation of water quality, it reveals the amount of free oxygen $\left(\mathrm{O}_{2}\right)$ dissolved in water which is necessary for sustaining and support aquatic life, so is human life (Chang, 2005). The dissolve oxygen standard requisites for aquatic life is $4 \mathrm{mg} \cdot \mathrm{l}^{-1}$, and for drinking purposes it is $6 \mathrm{mg} \cdot \mathrm{l}^{-1}$ (Alam, Islam, Muyen, Mamun \& Islam, 2007). The maximum and minimum values for DO in the current study were between 7.57 and $10.8 \mathrm{mg} \cdot 1^{-1}$, which means that all values of DO in water samples are above the recommended permissible limits. Generally, a higher DO level indicates better water quality.

Biochemical oxygen demand levels measured were between 0.33 and 8.37 $\mathrm{mg} \cdot \mathrm{l}^{-1}$. BOD is the amount of oxygen required to dismantle domestic and industrial pollutants present in the water source (De, 2003). According to WHO drinking water standard, BOD level of $3 \mathrm{mg} \cdot \mathrm{l}^{-1}$ is accepted and should not exceed $6 \mathrm{mg} \cdot \mathrm{l}^{-1}$. In the current study all the values of BOD were within the standards except in July (2013) were 8.37 and 8.22 for both monitoring stations (LZ2 and LZ3). Also, in November the BOD value was 4.3 for
LZ3 for the same year. The high values of BOD attributed to the existence of untreated wastewater flowing into river body.

Total hardness values were all in the range of the permissible limits, the minimum value of $\left(150 \mathrm{mg} \cdot \mathrm{l}^{-1}\right)$ recorded in December (2013) and the maximum $\left(235 \mathrm{mg} \cdot 1^{-1}\right)$ was in March (2018).

Total dissolved solids is the measure of the solid materials dissolved in the water sample. High levels of TDS causes harm effect to the public health as well as fish and aquatic plants. A serious danger can infect the nervous system of the human body by causing paralysis of the tongue, lips, face (Chang, 2005). In this study the range of TDS falls between 292 and $151 \mathrm{mg} \cdot \mathrm{l}^{-1}$, which is within the recommended value of $500 \mathrm{mg} \cdot \mathrm{l}^{-1}$ by the CCME (2001) and the WHO (2017) standards for water quality and specification limit for drinking water.

The electrical conductivity varies from 221.5 to $432 \mu \mathrm{S} \cdot \mathrm{cm}^{-1}$; and it is lies within the standards of drinking water.

The total alkalinity of water in this study ranged from 117 to $210 \mathrm{mg} \cdot \cdot^{-1}$, which is within the CCME (2001) standards of drinking water quality.

The TDS, TH, TA and EC parameters indicate the status of inorganic pollution, and represent the concentration of soluble salts in water (Turner \& Rabalais, 2003; Gupta, Vishvakarma \& Rawtani, 2009).

The minimum and maximum turbidity values of water in Lower Zab river were 4.9 NTU and 4,000 NTU, respectively. The maximum value for turbidity (4,000 and 1,100 NTU) recorded in November 2013 at the both stations LZ2 and LZ3. The reason for the high value of turbidity due to the end of the dry sea- 
sons (summer and autumn) and rainfall in the beginning of the rainy season. The increase of turbidity values results due to the high concentration of suspended matter in the water column, and subsequently increase dispersion of light. Which in turn causes in deterioration of the water quality, also will damage the aquatic life (Verma et al., 1984). For this purpose, the WHO, the CCME, and the IQS proposed a maximum range for turbidity of 5 NTU based on the processes used to treat wastewater (De, 2003).

The nitrate results obtained from the two sampled stations were higher than the maximum permissible limits proposed by the CCME (2001) for drinking water. The minimum and maximum values for nitrate were 0.147 and 16.44 $\mathrm{mg} \cdot \mathrm{l}^{-1}$. High nitrate levels in drinking water can be harmful to humans and cause serious illnesses such as "blue baby syndrome", cancer risks, and hemorrhaging of the spleen (Michalski \& Kurzyca, 2006; Aydin, 2007; Gupta et al., 2009; Yang \& Wang, 2010). Nitrites can also affect the aquatic life, plants and algae by decreased oxygen level when its concentrations rise in water (Davie \& Quinn, 2019).

Calcium concentrations in water samples were varying between 30 to 57 $\mathrm{mg} \cdot \mathrm{l}^{-1}$. All the data does not within the objective values suggested by the CCME (2001) for drinking water which is 25 $\mathrm{mg} \cdot \mathrm{l}^{-1}$. Approach results were obtained by Ewaid et al. (2018) in a study to assess the quality of water for the Tigris river. These results are due to the nature of the surrounding soil.

The potassium levels varying across the range of $1.02-40.8 \mathrm{mg} \cdot 1^{-1}$. In general, all the potassium levels were found to be within the accepted limits for drinking water quality standards. Except one value $\left(40.8 \mathrm{mg} \cdot 1^{-1}\right)$ recorded higher than the standards during winter in January 2017.

The results of the water quality index (WQI) at LZ2 station are shown in Figure 6. Both Canadian and NSF methods were used to calculate the WQI. It was noted that the WQI from 2013 to 2019 between marginal and fair status according to the CCME (Table 5). While the WQI are classified for the years 2013, 2015, 2016 as unsuitable for drinking and for 2014, 2019 as poor water and for 2017,2018 as a good water according to Table 4.

For LZ3 station, the results showed that the WQI from 2013 to 2019 are between marginal and fair status according to the CCME (Table 5). The results are same as the LZ2 station with some marginal decrease in the WQI. The decrease in the WQI possibly due to the polluting activity of the Lower Zab river mentioned in Table 2. In accordance to Table 4, the results showed that the WQI for 2013, 2015, 2016 years are unsuitable for drinking and for 2014, 2018, 2019 years are poor water and for the year of 2017 is good water. Also, it was noting that some marginal increase in the WQI value in which decreases the subtility of the water for drinking use (Fig. 7).

For the years 2014, 2015, and 2016, the water quality was degraded due to the ISIS war. Moreover, it was noted in the 2013 year that the water quality almost stable and have a constant value during spring and summer. A high decease in the water quality (high increase in WQI according to NSF Method) in the fall and winter seasons. This degradation in 


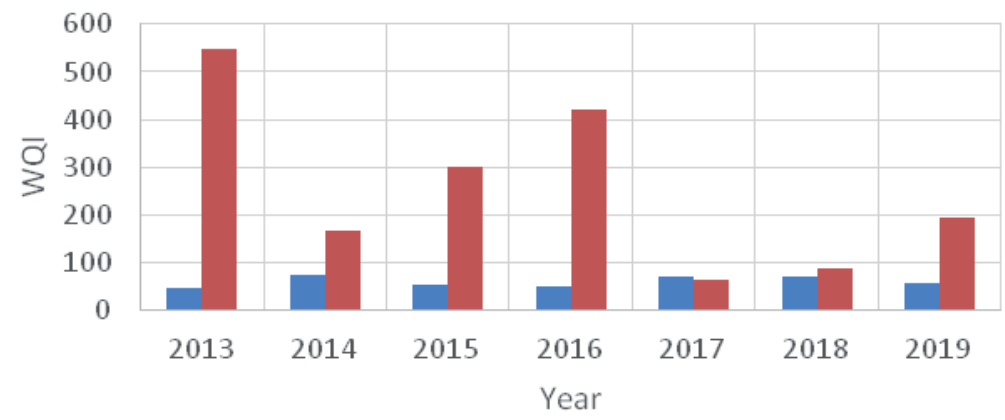

Canadian Method

NSF Method

FIGURE 6. Water Quality Index (WQI) at LZ2 station

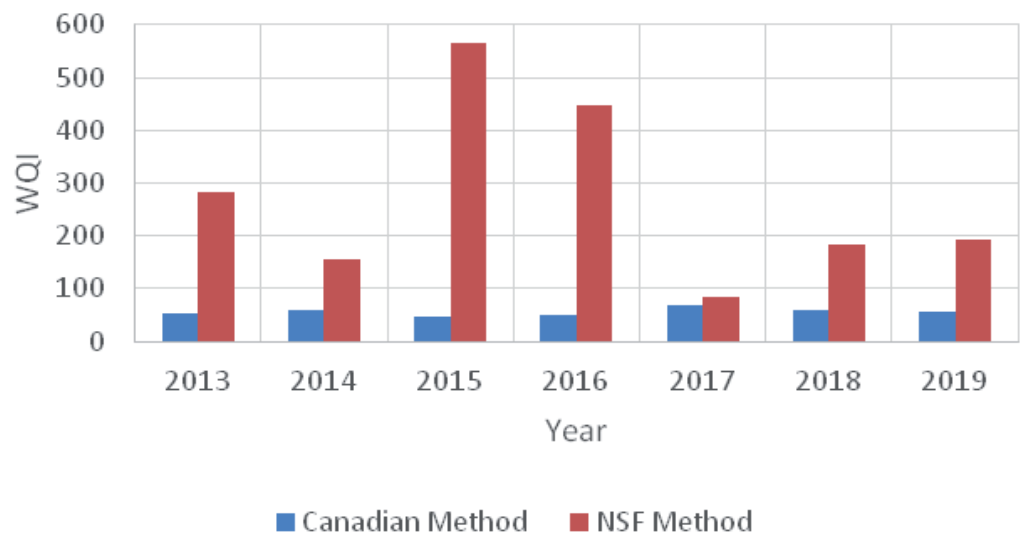

FIGURE 7. Water Quality Index (WQI) at LZ3 station

the water quality is due to that the earth has exposed to the long-dried season and then suddenly exposed to a high rainfall season which in turns leads to increase some parameters very high, i.e. turbidity (Fig. 8). Finally, the Lower Zab river water cannot be use for drinking directly. However, a pretreatment is needed before drinking use.

However, a recent research was noted that the quality of water are highly affected by seasons (Mena-Rivera, Salgado-Silva, Benavides-Benavides, Coto-Campos \& Swinscoe, 2017). Also it was noted previosuly that the quality of water in the spring is more better than other seasons (Ameen, 2019). Especially when the turbidity parameter is not included which gave good drinking water (Ewaid \& Abed, 2017). And this interpreted the varation in the WQI during seasons.

\section{Conclusions}

This research focused on the assessment of Lower Zab river water quality using both methods - Canadian Water 


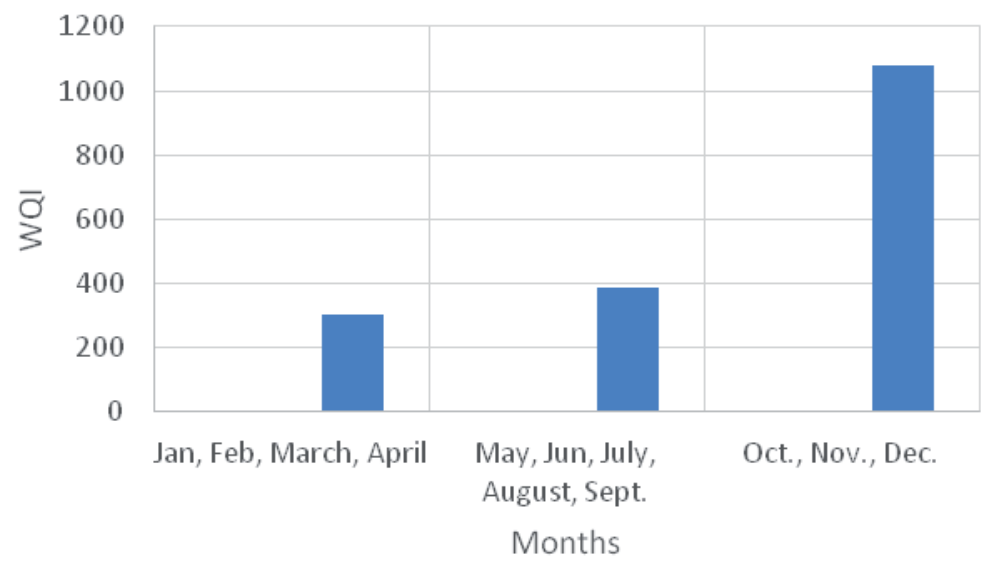

FIGURE 8. Water Quality Index (WQI) variation during year of 2013

Quality Index and NSF Water Quality Index. Two different stations LZ2 and LZ3 were selected for this study. The results show that all parameters values were within the standards of drinking water proposed by the CCME standards (2001), Iraqi standards (IQS 417, 2009), and the WHO standards (2017) for drinking purpose, except turbidity, DO, nitrate, calcium, which were mostly higher than the standards and occasionally BOD and potassium. Also, the results of WQI showed that the quality of water at LZ3 station is lower than the quality of water in the LZ2 station. This degradation in the quality of water is due to the polluting activity of the Lower Zab river (Table 2). Moreover, for the years 2014, 2015, and 2016, the water quality was degraded due to the ISIS war. However, the quality of the water is degraded in winter season more than summer season due to that the earth has exposed to the long-dried season and then suddenly exposed to a high rainfall season which in turns leads to increase some parameters very high (i.e. turbidity). Finally, the Lower Zab river water cannot be use for drinking directly. However, a pre-treatment is needed before the drinking use.

\section{References}

Akoto, O. \& Adiyiah, J. (2007). Chemical analysis of drinking water from some communities in the Brong Ahafo region. International Journal of Environmental Science \& Technology, 4(2), 211-214.

Al-Adawi, M.S. (2005). Water supply engineering. Alexandria: Alexandaria University Engineering College.

Alam, Md.J.B., Islam, M.R., Muyen, Z., Mamun, M. \& Islam, S. (2007). Water quality parameters along rivers. International Journal of Environmental Science \& Technology, 4(1), 159-167. https://doi.org/10.1007/ bf03325974

Al-Ansari, N. (2016). Hydro-politics of the Tigris and Euphrates basins. Engineering, 8(3), 140-172. https://doi.org/10.4236/eng.2016.83015

Al-Heety, E.A.M., Turki, A.M. \& Al-Othman, E.M. (2011). Assessment of the water quality index of Euphrates river between Heet and Ramadi cities, Iraq. International Journal of Basic \& Applied Sciences, 11(6), 38-47.

Al-Mutairi, N., Abahussain, A. \& El-Battay, A. (2014). Application of Water Quality Index to assess the environmental quality of Kuwait Bay. In AABES-2014: International Confer- 
ence on Advances in Agricultural, Biological and Environmental Sciences. Dubai, UAE, 15-16.10.2014. Dubai: AABES-2014.

Alobaidy, A.H.M.J, Abid, H.S. \& Maulood, B.K. (2010). Application of Water Quality Index for assessment of Dokan lake ecosystem, Kurdistan Region, Iraq. Journal of Water Resource and Protection, 2(9), 792-798. https://doi.org/10.4236/jwarp.2010.29093

Ameen, H.A. (2019). Spring water quality assessment using water quality index in villages of Barwari Bala, Duhok, Kurdistan Region, Iraq. Applied Water Science, 9(8), 176. https://doi.org/10.1007/s13201-019-1080-z

American Public Health Association [APHA] (1995). Standard Methods for the Examination of Water and Wastewater. $19^{\text {th }}$ ed. New York: APHA.

Aydin, A. (2007). The microbiological and physico-chemical quality of groundwater in West Thrace, Turkey. Polish Journal of Environmental Studies, 16(3), 377-383.

Bangladesh Center for Advance Studies [BCAS] (2000). Pollution study, management of aquatic ecosystem through community husbandry (MACH). Dhaka, Bangladesh: Bangladesh Center for Advance Studies.

Batabyal, A.K. \& Chakraborty, S. (2015). Hydrogeochemistry and Water Quality Index in the assessment of groundwater quality for drinking uses. Water Environment Research, 87(7), 607-617. https://doi.org/10.2175/ $106143015 \times 14212658613956$

Brown, R.M., McClelland, N.I., Deininger, R.A. \& Tozer, R.G. (1970). A water quality index: do we dare? Water and Sewage Works, 117, 339-343.

Canadian Council of Ministers of the Environment [CCME] (2001). Canadian water quality guidelines for the protection of aquatic life: CCME Water Quality Index 1.0. User's Manual. Winnipeg: CCME.

Chang, H. (2005). Spatial and temporal variations of water quality in the Han river and its tributaries, Seoul, Korea, 1993-2002. Water, Air, and Soil Pollution, 161(1), 267-284. https://doi.org/10.1007/s11270-005-4286-7

Damo, R. \& Icka, P. (2013). Evaluation of Water Quality Index for drinking water. Polish Journal of Environmental Studies, 22(4), 1045-1051.
Davie, T. \& Quinn, N.W. (2019). Fundamentals of hydrology. Abingdon: Routledge.

De, A.K. (2003). Environmental chemistry. New Delhi: New Age International.

Ebuete, A.W. \& Ebuete, I.Y. (2018). Water quality of Kolo Creek in Bayelsa State by means of Water Quality Index for missing parameters. International Journal of Innovative Research and Advanced Studies, 5(8), 53-60.

Eulisse, E. (2010). Challenges in water resources management. Venezia, Italy: Marie Curie Training Course.

Ewaid, S.H. \& Abed, S.A. (2017). Water quality index for Al-Gharraf river, southern Iraq. The Egyptian Journal of Aquatic Research, 43(2), 117-122. https://doi.org/10.1016/ j.ejar.2017.03.001

Ewaid, S.H., Abed, S.A. \& Kadhum, S.A. (2018). Predicting the Tigris river water quality within Baghdad, Iraq by using water quality index and regression analysis. Environmental Technology \& Innovation, 11, 390-398. https://doi.org/10.1016/j.eti.2018.06.013

Frenken, K. (2009). Irrigation in the Middle East region in figures. Rome: FAO Water Reports.

Fulazzaky, M.A. (2009). Water quality evaluation system to assess the Brantas river water. Water Resources Management, 23(14), 3019-3033. https://doi.org/10.1007/s11269-009-9421-6

Glińska-Lewczuk, K. (2006). Effect of land use and lake presence on chemical diversity of the Łyna river system. Polish Journal of Environmental Studies, 15(2), 259-269.

Gupta, N., Pandey, P. \& Hussain, J. (2017). Effect of physicochemical and biological parameters on the quality of river water of Narmada, Madhya Pradesh, India. Water Science, 31(1), 11-23. https://doi.org/10.1016/ j.wsj.2017.03.002

Gupta, P., Vishvakarma, M. \& Rawtani, P.M. (2009). Assesment of water quality parameters of Kerwa Dam for drinking suitability. International Journal of Theoretical \& Applied Sciences, 1(2), 53-55.

Horton, R.K. (1965). An index number system for rating water quality. Journal of the Water Pollution Control Federation, 37(3), 300-305 .

House, M.A. \& Ellis, J.B. (1987). The development of water quality indices for operational 
management. Water Science and Technology, 19(9), 145-154. https://doi.org/10.2166/ wst. 1987.0076

IQS 417 (2009). Iraqi criteria and standards for drinking water, chemical limits. In ICS 13.060.20. Drinking water.

Jabar, R.A.A. (2008). Effects of some physical and chemical factors of Lower Zab water on Tigris river. Tikrit Journal of Pure Science, 13(1), 132-142.

Kašiarová, S. \& Feszterová, M. (2010). Changes in stream water contamination in select Slovakian settlements. Polish Journal of Environmental Studies, 19(2), 343-349.

Kassim, T.I., Sabri, A.W. \& Salman, M.S. (2007). The limnological effects of river lesser-Zab on Tigris river, Iraq. Um-Salama Science Journal, 4(3), 452-457.

Khan, A.A., Paterson, R. \& Khan, H. (2004). Modification and application of the Canadian Council of Ministers of the Environment Water Quality Index (CCME WQI) for the communication of drinking water quality data in Newfoundland and Labrador. Water Quality Research Journal, 39(3), 285-293. https://doi.org/10.2166/wqrj.2004.039

Khan, A.A., Tobin, A., Paterson, R., Khan, H. \& Warren, R. (2005). Application of CCME procedures for deriving site-specific water quality guidelines for the CCME Water Quality Index. Water Quality Research Journal, 40(4), 448-456. https://doi.org/10.2166/ wqrj.2005.047

Khan, H., Khan, A.A. \& Hall, S. (2005). The Canadian Water Quality Index: a tool for water resources management. In MTERM International Conference. Bangkok, Thailand, 6-10.06.2005. Thailand. Bangkok: AIT.

Kliot, N. (2005). Water resources and conflict in the Middle East. Abington: Routledge.

Kumar, D. \& Alappat, B.J. (2009). NSF-Water Quality Index: does it represent the experts' opinion? Practice Periodical of Hazardous, Toxic, and Radioactive Waste Management, 13(1), 75-79. https://doi.org/10.1061/ (ASCE)1090-025X(2009)13:1(75)

Kumari, B.L., Sudhakar, P., Sri, M.H. \& Sree, K.P.N.V.S. (2011). Analysis of physicochemical parameters of water quality in and around Saltpans of Prakasam (Dt.) A.P. Journal of Ecobiotechnology, 3(10), 1-6.
Lumb, A., Halliwell, D. \& Sharma, T. (2006). Application of CCME Water Quality Index to monitor water quality: a case study of the Mackenzie river basin, Canada. Environmental Monitoring and Assessment, 113(1), 411-429. https://doi.org/10.1007/s10661005-9092-6

Mahagamage, M.G.Y.L. \& Manage, P.M. (2014). Water Quality Index (CCME-WQI) based assessment study of water quality in Kelani river basin, Sri Lanka. The 1st Environment and Natural Resources International Conference. Bangkok, Thailand, 6-7.11.2014.

Mena-Rivera, L., Salgado-Silva, V., Benavides-Benavides, C., Coto-Campos, J.M. \& Swinscoe, T.H.A. (2017). Spatial and seasonal surface water quality assessment in a tropical urban catchment: Burío River, Costa Rica. Water, 9(8), 558. https://doi.org/10.3390/ w9080558

Michalski, R. \& Kurzyca, I. (2006). Determination of nitrogen species (nitrate, nitrite and ammonia ions) in environmental samples by ion chromatography. Polish Journal of Environmental Studies, 15(1), 5-18.

Munna, Md.G., Chowdhury, M., Ahmed, A.A., Chowdhury, S. \& Alom, Md.M. (2013). A Canadian Water Quality Guideline-Water Quality Index (CCME-WQI) based assessment study of water quality in Surma river. Journal of Civil Engineering and Construction Technology, 4(3), 81-89. https://doi. org/10.5897/JCECT12.074

Nas, S.S., Bayram, A., Nas, E. \& Bulut, V.N. (2008). Effects of some water quality parameters on the dissolved oxygen balance of streams. Polish Journal of Environmental Studies, 17(4), 531-538.

Nollet, L.M.L. (ed.) (2004). Handbook of water analysis. Boca Raton: CRC Press.

Ott, W.R. (1978). Water Quality Index. A survey of indices used in the United States. Washington: Environmental Protection Agency.

Panduranga Murthy, G., \& Hosmani, S.P. (2009). Water Quality Index (WQI) to evaluate surface water quality for protection of aquatic life: a case study: Bherya Lake, Mysore, Karnataka State, India. 13th World Lake Conference. Wuhan, China, 01-05.11.2009.

Phadatare, S.S. \& Gawande, S. (2016). Review paper on development of Water Quality 
Index. International Journal of Engineering and Technical Research, 5(5), 765-767.

Rabee, A.M., Abdul-Kareem, B.M. \& Al-Dhamin, A.S. (2011). Seasonal variations of some ecological parameters in Tigris river water at Baghdad Region, Iraq. Journal of Water Resource and Protection, 3(4), 262-267.

Rajankar, P.N., Gulhane, S.R., Tambekar, D.H., Ramteke, D.S. \& Wate, S.R. (2009). Water quality assessment of groundwater resources in Nagpur Region (India) Based on WQI. E-Journal of Chemistry, 6(3), 905-908. https:// doi.org/10.1155/2009/971242

Reza, R. \& Singh, G. (2010). Assessment of ground water quality status by using Water Quality Index Method in Orissa, India. World Applied Sciences Journal, 9(12), 1392-1397.

Saeedrashed, Y. \& Guven, A. (2013). Estimation of geomorphological parameters of lower Zab river-basin by using GIS-based remotely sensed image. Journal of Water Resource Management, 27(1), 209-2019.

Schultz, M.T. (2001). A critique of EPA's index of watershed indicators. Journal of Environmental Management, 62(4), 429-442. https:// doi.org/10.1006/jema.2001.0451

Shahin, M. (2007). Water resources and hydrometeorology of the Arab Region. Dordrecht: Springer Netherlands.

Shiklomanov, I. (1993). World fresh water resources. In P. Gleick (ed.), Water in crisis: a guide to the world's fresh water resources (pp. 13-24). Oxford: Oxford University Press.

Srivastava, G. \& Kumar, P.R. (2013). Water Quality Index with missing parameters. International Journal of Research in Engineering and Technology, 2(4), 609-614. https://doi. org/10.15623/ijret.2013.0204035

Turner, R.E. \& Rabalais, N.N. (2003). Linking landscape and water quality in the Mississippi river basin for 200 years. BioScience, 53(6), 563-572. https://doi.org/10.1641/00063568(2003)053[0563:1lawqi]2.0.co;2

Tyagi, S., Sharma, B., Singh, P. \& Dobhal, R. (2013). Water quality assessment in terms of Water Quality Index. American Journal of Water Resources, 1(3), 34-38.

Verma, S.R., Sharma, P., Tyagi, A., Rani, S., Gupta, A.K. \& Dalela, R.C. (1984). Pollution and saprobic status of Eastern Kalinadi. Limnologia (Berlin), 15, 69-133.
Witek, Z. \& Jarosiewicz, A. (2009). Long-term changes in nutrient status of river water. Polish Journal of Environmental Studies, 18(6), 1177-1184.

World Health Organization [WHO] (2001). WHO World Water Day Report. Geneva: WHO.

World Health Organization [WHO] (2017). Guidelines for drinking water quality. Geneva: WHO.

Yang, Y.S. \& Wang, L. (2010). Catchment-scale vulnerability assessment of groundwater pollution from diffuse sources using the DRASTIC method: a case study. Hydrological Sciences Journal, 55(7), 1206-1216. https://doi. org/10.1080/02626667.2010.508872

\section{Summary}

Assessment of Lower Zab river water quality using both Canadian Water Quality Index Method and NSF Water Quality Index Method. Rivers are considered the most important sources of surface water on Earth. They are play a significant role in all human activities and the quality of river water is needed. Therefore, the importance of the water quality index is arising through providing data base about quality of the water source, and explain the change in the water quality over a period of time continually. This study involved determination of physicochemical and biological parameters of Lower Zab river in Kirkuk city at two different points. The objectives of the study are to assess the present water quality, through analysis of some selected water quality parameters like $\mathrm{pH}$, TDS, BOD, dissolved oxygen, turbidity, EC, alkalinity, and salinity etc. and to compare the results with the Canadian Council of Ministers of the Environment and National Sanitation Foundation Water Quality Indices. Raw water samples were collected from the Lower Zab river twice a month by one sample every 15 days from each station. The water quality data include 16 different parameters. Tests were carried out following the American Public Health Association standard methods. The results 
show that all parameters values were within the standards of drinking water proposed by the CCME standards and Iraqi standards or the World Health Organization standards for drinking purpose, except turbidity, DO, nitrate, calcium, which were mostly higher than the standards and sometimes BOD and potassium. The results of WQI showed that the water quality at LZ3 station is lower than LZ2 station due to the polluting activity of the Lower Zab river. Furthermore, for the years 2014, 2015, and 2016, the water quality was degraded due to the ISIS war. Also, it was noted in the 2013 year that the water quality degraded more in fall and winter seasons due to that the earth has exposed to the long-dried season and then suddenly exposed to a high rainfall season which in turns leads to increase some parameters very high (i.e. turbidity). Finally, the Lower Zab river water cannot be use for drinking directly. However, a pretreatment is needed before the drinking use.

\section{Authors' address:}

Sarah Mustafa Ahmed

(https://orcid.org/0000-0002-0965-3433)

University of Kirkuk

Environmental Research Unit

36013, Kirkuk, Iraq

e-mail: sarahmustafa@uokirkuk.edu.iq

Omer Muhie Eldeen Taha

(https://orcid.org/0000-0003-4922-7778)

University of Kirkuk

Department of Civil Engineering

36013, Kirkuk, Iraq

e-mail: omer.muhie@uokirkuk.edu.iq 